\title{
Legal Nature of the Contract of Succession as a Special Institute of Civil Law of the Russian Federation
}

\author{
Liliya Zakievna Gazizullina ${ }^{1} \&$ Irina Mikhailovna Sboeva ${ }^{1}$ \\ ${ }^{1}$ Kazan Federal University, Russia \\ Correspondence: Liliya Zakievna Gazizullina, Kazan Federal University, Russia. E-mail: 89196873238@mail.ru
}

Received: June 9, 2019

Accepted: August 25, $2019 \quad$ Online Published: September 3, 2019

doi:10.5539/jpl.v12n5p151

URL: https://doi.org/10.5539/jpl.v12n5p151

\begin{abstract}
In this paper, the authors analyse a new institution for the Russian legal system, namely, the contract of succession institution. It is a qualitatively new way to transfer property, which was legislated as a supplement to the existing grounds of succession.

It is noted that one of the advantages of this type of succession is that this type of agreement enables a property owner not only to outline the circle of successors during his/her lifetime but also to stipulate clear conditions for their entry into rights of succession. That is, thanks to this agreement, it becomes possible to determine to whom and what kind of property will be transferred after the death of the owner, and what conditions must be met for this.

In this paper, the authors correlate a contract of succession with mixed categories: they compare (only by some criteria) a contract of succession with a unilateral transaction - a last will and testament.

The authors conclude that the institution of the contract of succession is a symbiosis of succession and contractual legal relations (mixed nature), which may lead to certain problems in the future during the enforcement of the current legislation.
\end{abstract}

Keywords: succession, contract of succession, antecessor, heir, notary

\section{Introduction}

Federal Law dated July 19, 2018, No. 217-FZ "On Amending Article 256, Part One, and Part Three of the Civil Code of the Russian Federation" amended paragraph 1 of Article 1118, the Civil Code of the Russian Federation (hereinafter - the Code). According to them, since June 1, 2019, the list of grounds for succession has expanded: in addition to such classical grounds as testamentary succession, including the joint last will and testament of spouses, and hereditary succession, succession under the contract of succession has appeared. Thus, the institution which is widely recognized in many foreign countries: Austria, England, Germany, China, Ukraine, the USA, Switzerland, and others, become to be in the picture in the Russian legal system now.

The design of the contract of succession as an "act of solemn transfer of property in the event of death" to a person who "became a "natural successor" appeared thanks to Roman lawyers and was later borrowed by German law. This, according to F. Lassale, determined the legal force of the contract of successions in German law.

Later, the essential features of the contract of succession enshrined in the German Civil Code (hereinafter - the Code), were borrowed by the legal systems of Austria, Switzerland and other European countries.

It should also be noted that at present, the contracts of succession have received sufficient distribution in many foreign countries. For example, in Germany, the share of contracts of succession is $15 \%$ of all succession relations, in England - 46.8\%, in Switzerland - 75\%. The above data indicate that the contract of succession as the basis of succession is not only applied on a par with the traditional last will and testament but in some countries even prevails over it.

\section{Methods}

The concept of "contract of succession" is contained in Article 1140.1 of the Code. According to it, the antecessor is given the right to conclude a contract, the terms of which determine both the circle of heirs and the procedure for transfer of rights to the antecessor's property after his/her death to the parties of the antecessor who have survived the antecessor or to surviving third parties who may be called upon for succession. In this case, the contract of succession may be concluded with persons, the list of which is specified in Article 1116 of the Code: individuals 
(citizens), legal entities of the Russian Federation, its subjects, municipalities, foreign states, and international organizations.

The version for the definition of the contract of succession proposed by the Code, which suggests treating it as a "testamentary arrangement which is drawn up by two or more persons in the form of an agreement under which the antecessor appoints the second party to the agreement or a third party as his/her heir," indicates a common understanding of this institution. In turn, according to the definition contained in paragraphs 1 and 2 of $\S 1941$ of the Code, a contract of succession is a mutual agreement by which a person can appoint another person (whether or not the other party to the agreement) to be the heir to all of his/her property or its part, or the legatee when establishing the legate.

At the beginning of its inception, the contract of succession in England was called the "mirror last will and testament", although, in essence, it is much closer to the marriage contract than to the last will and testament. Later, thanks to a judicial precedent, a contract of succession was equated with "mutual last will and testaments", by which the courts began to understand an agreement according to which the parties mutually undertake to appoint each other as heirs (that is, this agreement has a bilateral binding character) or a third party.

Touching upon the legal nature of the contract of succession, it should be noted that at present there is no unanimous opinion regarding its legal nature.

So, according to H.L. Graf, in Germany, the German Civil Code notes the mixed nature of the contract of succession: succession legal and contractual legal. In particular, O.A. Puchkov and V.O. Puchkov in their article note, that in the science of German civil law, there is the concept of "transactions between the living in case of death" (Zuwendungen unter Lebenden auf den Todesfall), which include the contract of succession. In addition, M. Harder notes that, in fact, they are property transactions, the legal consequences of which arise after the death of one of the parties. In turn, H.-A. Weirich pointed out the possibility of applying general provisions on transactions to a contract of succession (invalidation in case of abuse of rights - \$2287, contestation before opening the succession - \$2283, termination of the contract of succession - clause $3 \$ 2298$ of the Code), general provisions on contracts - in terms of conclusion contract of succession. The above, with no doubt, confirm the contractual legal nature of the design.

The English model of the contract of succession has some similarities with the German one. However, recently the understanding of the contract of succession in English civil law is beginning to change. So, if earlier the judicial practice recognized the succession and legal problem of "mutual testament", then at present courts are more and more inclined towards its legal nature. An example is the judgment of the Court of Appeal of England and Wales in Walters v. Olins, according to which a mutual testament, it is also a contract of succession, can contain conditions not only of a proprietary law but also of a binding legal nature, since the application of exclusive provisions on last will and testaments established by law makes it possible to ensure an adequate level of legal regulation of a mutual testament. It was by virtue of these circumstances the court indicated that "mutual last will and testaments" should also be governed by the provisions of contract law and should obey the rules on the procedural protection of contractual relations. It is advisable to agree with the opinion by O.A. Puchkov and V.O. Puchkov, who note that "having historically formed in the legal succession field, the English "mutual testament" gradually acquired more and more contractual elements, which led to the fact that the English judicial practice began to interpret the "mutual testament" as primarily a civil law agreement (a contract of succession)".

Despite the fact that the institution of the contract of succession is new to the Russian legal system, it should be noted that it is characterized by a mixed nature: succession legal and contractual legal.

This is due to the fact that, on the one hand, it is regulated by the rules of the third part of the Russian Civil Code, which regulates the provisions on succession. On the other hand, it is characterized by signs of a civil law transaction. So, by agreement of the parties, a contract of succession may not only include a condition on the executor. It may also contain an obligation to commit by persons who participate in the contract of succession and may be called upon for succession, any actions that are not contrary to the law of a property nature (for example, life support of the antecessor, which gives some similarities with an annuity agreement) or non-property nature (for example, care for the antecessor during his/her lifetime).

In the sense of the legislator, a contract of succession may contain an obligation to execute testamentary refusals (transfer of the ownership, possession on another property right or use of a thing that is part of a succession; transfer of property right that is part of a succession; acquisition for a legatee and transfer to him/her of another property; performing certain work for him/her or rendering certain services to him/her or making periodic payments to the legatee, etc.) or testamentary burdens (obligation to make an act of property or non-pecuniary nature aimed at the implementation of generally useful purpose or to implement another legitimate goal). 
The consequences stipulated by a contract of succession may be made dependent on the circumstances that occurred by the day the succession was opened, regarding which it was not known at the conclusion of the contract of succession whether they would occur or not. In particular, they depend on circumstances that are completely dependent on the last will of one of the parties.

Consequently, depending on the presence of a counterpromise of the heir in relation to the antecessor, the contract of succession may be both onerous and free of charge. Since the contract of succession provides for the inclusion of potestative conditions, it can be conditional or unconditional.

\section{Results and Discussion}

We will conduct a comparative analysis of only some of the signs of a contract of succession and last will and testament. So, the contract of succession and testament are similar to each other for the following reasons.

Firstly, both a last will and testament and a contract of succession can be made by a citizen who, at the time of its commission, was fully capable, in person (execution of a testament and the conclusion of a contract of succession through a representative are not allowed).

Secondly, both for a last will and testament executed by citizens who are married to each other at the time of its execution, and for a contract of succession, such grounds for the loss of force as dissolution of marriage and avoidance of the marriage are provided. There is one small clarification: a joint testament of the spouses becomes null and void if the marriage is declared invalid both before and after the death of one of the spouses.

Thirdly, the conditions of the last will and testament, as well as the conditions of the contract of succession, apply in so far as they do not contradict the rules on the mandatory share in the succession, including the mandatory share in the succession, the right to which appeared after the completion of the last will and testament or conclusion of the contract of succession, and also on the prohibition of succession by unworthy heirs.

Fourth, both after the execution of the last will and testament and after the conclusion of the contract of succession, the antecessor has the right to make any transactions in relation to his property and to otherwise dispose of the property belonging to him/her with his/her last will and testament and in his/her interest, even if such an order deprives a person who may be called for succession, rights to the property of the antecessor.

Fifthly, a contract of succession may, like a last will and testament, contain a clause on the executor and impose on the persons participating in the contract of succession who may be called upon for succession, the obligation to commit any actions of a property or non-property nature that do not contradict the law, including execution of testamentary refusals or testamentary impositions.

Sixth, it should be noted that all persons involved in one way or another in the verification of the contract of succession must observe the secrecy of the specified action. The legislator classifies such persons as a notary, translator, witnesses, parties to the contract of succession, notaries who have access to the information contained in the unified notary information system, as well as citizens signing the contract of succession. These persons are obligated not to disclose information regarding the contents of the contract of succession, its execution, conclusion, amendment or cancellation, until the opening of the succession.

\section{Summary}

As mentioned earlier, the institutions analysed have fundamental differences.

Firstly, a last will and testament is a unilateral transaction representing a citizen's disposition of his/her property in the event of death, and a contract of succession is a bilateral agreement that also represents a citizen's disposition of his/her property.

Secondly, the last will and testament create rights and obligations only after the opening of the succession. In turn, the rights and obligations stipulated by the contract of succession may arise both after the opening of the succession and before its opening (for example, the duties that arise before the opening of the succession by virtue of the contract of succession must be fulfilled before the opening of the succession and assigned to that side of the agreement which may be called for succession by the antecessor).

Thirdly, a last will and testament can be made not only by one citizen but also by citizens who are married among themselves at the time of its execution; only an antecessor solely can act as a party to the contract of succession.

Fourthly, an antecessor is given the right to conclude one or more contracts of succession with one or more persons who may be called upon for succession. Moreover, if one property of the antecessor was the subject of several contracts of succession concluded with different persons, then if they accept the succession, the contract of succession that was concluded earlier should be applied. Thus, the legislator secures the priority of the original 
contract of succession. A different rule is provided for testaments: a subsequent testament cancels the previous testament in full or in part in which it contradicts the subsequent testament.

Fifthly, a contract of succession and a testament also differ in respect to the form of certification: a testament must be certified by a notary and other persons (clause 7 of article 1125, clause 1127 and clause 2 of article 1128 of the Civil Code), as an exception, its certification in simple written form (Article 1129 of the Civil Code) is accepted. In turn, there are no exceptions to the rules for a contract of succession: it is subject to mandatory notarization.

Sixth, in contrast to testaments (which are essentially unconditional transactions), the consequences stipulated by a contract of succession can be made dependent on the circumstances that occurred on the day the succession was opened, and regarding which it was not known at the moment when the contract of succession was concluded whether they will occur or not. This, in particular, was affected by circumstances completely dependent on the will of one of the parties.

According to the general rule, when certifying a contract of succession, a notary is obliged to carry out a video recording of the procedure for concluding the estate agreement. This action must be in strict accordance with the Procedure for using notaries of video recording means and storage of video recording materials, approved by the decision of the Board of the Federal Notary Chamber. This obligation may not be performed by a notary only if the parties to the contract of succession have objected to the video recording of this procedure. If we are talking about the certification of a testament, the obligation to its video recording is not enshrined in the legislation.

\section{Conclusions}

Thus, a contract of succession is a special basis for succession, which aims to maximize the safety of both an antecessor and his/her property, the transfer of which is planned in case of death of a citizen, from undesirable actions of third parties. Upon that, the legislator gives priority to the contract of succession. This circumstance is manifested in the fact that if a testament and a contract of succession containing an indication of the same property are found after the antecessor's death, the provisions of the contract of succession will be applied, and the last will and testament will be declared invalid.

Attention should be paid to the essential similarity between the contract of succession and the life estate agreement. However, in this case, the contract of succession is more advantageous for the following reasons: firstly, the life estate agreement involves the placing on the annuity payer of duty to care and maintain the annuity recipient during his/her lifetime. In turn, the contract of succession provides for the possibility to impose not only property but also non-property obligations, the fulfilment of which is possible either during life or after the death of the antecessor. In addition, the transfer of the property ownership for rental relations, which is the subject of the contract is carried out after signing the contract, its notarization and state registration of the transfer of ownership, and the transfer of ownership under the contract of succession takes place after the death of the antecessor and only if the other party fulfils all obligations under the contract.

\section{Acknowledgements}

The work is performed according to the Russian Government Program of Competitive Growth of Kazan Federal University.

\section{References}

Bürgerliches Gesetzbuch. Januar. - 2002 (BGBl. I S. 42, ber. S. 2909, ber. 2003 I S. 738).

Civil Code of the Russian Federation (part three) dated 11/26/2001№146-FZ. Collected legislation of the Russian Federation. 12/03/2001, No. 49. Art. 4552.

Federal Law No. 217-FZ dated July 19, 2018 "On Amendments to Article 256 of Part One and Part Three of the Civil Code of the Russian Federation”. Collected Legislation of the Russian Federation. 07/23/2018, No. 30. Art. 4552.

Gazizullina, L. Z. (2019). Joint testament of spouses - a new institution in Russian law. Science Innovations: a collection of articles of the International Scientific and Practical Conference (May 30, 2019). Petrozavodsk: ICNP "New Science". pp. 96-101.

Graf, H. L. (2010). Nachlaßrecht. Handbuch der Rechtspraxis. 8 Auflage. München: CH Beck`sche Verlagsbuchhandlung.

Harder, M. (2008). Zuwendungen unter Lebenden auf Todesfall. Ducker \& Humbolt. Berlin.

Kurdinovsky VI Contracts of succession. Notes of the Faculty of Law, Imperial Novorossiysk University. Issue IX, edited by I. D. Ord., Professor A.P. Dobroklonsky. Odessa: Printing House Technician, 1912. 
Kusitzky, A. (2007). Ihr Last will and testamente geschehe. Focus, (5), 112.

Lassale F. Das System der erworbenen Rechte / - 1861 II. Das Wesen des germanishen Erbrechts. 573 p.

Lorenz, D. V. (2015). Agreement on the Alienation of Property in the Event of Death. Notary Gazette, (5), 40-42.

Orley, R., \& Lilly, Jr. (1984). Will Contracts: Contract Rights in Conflict with Spousal Rights. Tusla Law Review, 20(2).

Puchkov, O. A., \& Puchkov, V. O. (2016). Contract of succession as a special institution of civil law of foreign states: a general characteristic. Law and order: history, theory, practice, (3), 34-39.

Re Oldham, [1925] 1 Ch. 75, 84 (Ch. 1924).

Reimann, M. (2014). Einfuhrung in das US: amerikansche Privatrecht. 2. Aufl. M nchen. 378 p.

Robert, K., Miller, Jr., \& McNamee, S. J. (1997). Succession and Wealth in America. Springer Silence + Business Media, LLC.

Weirich, H.-A. (2014). Erben und Vererben: Handbuch des Erbrechts und der vorweggenommenen Vermögensnachfolge. Herne; Berlin: Verlag Neue Wirtschafts-Briefe.

\section{Copyrights}

Copyright for this article is retained by the author(s), with first publication rights granted to the journal.

This is an open-access article distributed under the terms and conditions of the Creative Commons Attribution license (http://creativecommons.org/licenses/by/4.0/). 